\title{
COMMUNITY EMPOWERMENT PROGRAM TO INCREASE COMMUNITY INCOME IN SITIMULYO VILLAGE, PIYUNGAN DISTRICT, YOGYAKARTA
}

\author{
Heppi Marta Cristina ${ }^{1}$ \\ ${ }^{1}$ Sekolah Pascasarjana, Universitas Negeri Yogyakarta, Indonesia
}

DOI: 10.23917/humaniora.v20i2.9222

Received: May $5^{\text {th }}, 2020$. Revised: June $10^{\text {th }}, 2020$. Accepted: June $23^{\text {rd }}, 2020$

Available Online: August $29^{\text {th }}$, 2020. Published Regulary: August, 2020

\begin{tabular}{l} 
Keywords \\
\hline empowerment, \\
program, \\
improvement revenue
\end{tabular}

Corresponding

\section{Author}

Heppi Marta Cristina Universitas Negeri

Yogyakarta, Indonesia

Email:

heppi.martha@gmail.com

\section{Abstract}

The community empowerment program is a program provided to the community by conducting training to improve human resources and community income through local governments. The purpose of this study was to analyze the community empowerment program that will be implemented to increase community income in the Sitimulyo Village, Piyungan District, Bantul, Yogyakarta. Qualitative research method was used. The number of samples in the study were 30 respondents, data collection techniques used interviews supported by observation as well as secondary data and primary data. The results showed that the community empowerment program with the OVOP approach with training related to activities to increase skills development and entrepreneurship had been carried out by village officials through village community empowerment activities. That the empowerment program through the OVOP approach or One Vilage One Product is a training carried out by the local government, especially village officials with activities to increase community income through skills training and entrepreneurship by participating in the community in a good rated training program that will be given to the community successfully because of the enthusiasm of the invited community in following the training program. Village officials always try to provide any kind of assistance in terms of tools, materials and services for the success of the community empowerment program. This training program will increase community knowledge and skills in making a product by utilizing a variety of local food and so on until it can be produced which can later become an entrepreneur. Community empowerment with the OVOP approach is an empowerment program directed at (1) enabling, namely the creation of a climate capable of encouraging the development of community potential, (2) empowering, namely the potential possessed by the community is further strengthened and (3) protecting the potential of the weak community in all respects balanced protection is needed so that the competition formed runs healthily in an effort to make the community have the ability to run a business so as to increase people's income.

\section{INTRODUCTION}

The problem that occurs in village development today is one of the problems that should not be ignored and must be considered, because it is closely related to the progress and prosperity of an area. For this reason, strategic steps are needed to prepare human 
resources in each village. Village Development greatly influences a country's good growth, both political, social, economic, and social. Therefore development must be considered by a Region and the government so that the progress and prosperity of a Region and State can be achieved. Village Development cannot be separated from the characteristics of the community and its readiness in facing the population demographic leap.

Indonesia is meant to be one of the countries with quite a number of villages and still has not been well developed and evenly distributed village development, especially in terms of resources, local food products and entrepreneurship that have not been properly touched so as to make some villages lag behind. Therefore, overcoming these problems requires coordinating steps that are responsive and real. Community empowerment is a very relevant effort and a priority to be carried out, especially in areas in Indonesia that are prone to villages that make use of village development.

Siti Mulyo village, Piyungan sub-district is one of the villages located in Yogyakarta. The population tends to settle in groups in areas that have a flat and higher surface, henceforth this area is called Dusun. This happens because the land that is below and flat can be used as agricultural land. The majority of the social conditions of the Sitimulyo Village community are porductive age (ages 18 to 49) years with varying levels and educational backgrounds so that the level of welfare and living standards varies.

The history of the founding of the Sitimulyo Village began with a change in the kingdom system of the State of Ngayogyakarta Hadiningrat. At that time the government of an area was led by a Bekel and Demang, then merged into the Village. The establishment of villages in the Ngayogyakarta Hadiningrat Region also influenced the establishment of Sitimulyo Village, which is a combination of Mojosari, Madugondo, Cepokjajar and Ngablak Villages.

However, there are several issues related to Siti Mulyo Village, namely the amount of vacant land that has not been utilized, one of which is entrepreneurship that is not yet in the village of Sitimulyo and has not been considered and also the use of local products that have not been managed well when sold later as by the village sitymulyo can increase village income.

From the results of a review conducted in Sitimulyo Village on February 7, 2019 with a team from LPPM and the village apparatus, there are still vacant lands that have not been utilized properly, there are no entrepreneurial centers or MSMEs, and the results of local products that have not been utilized, community background is still many especially the women whose work is only collecting garbage for resale, this points to the lack of skills from the community to have the potential to develop entrepreneurship, especially for local products from the village of Siti Mulyo.

Public welfare is the goal of economic development in accordance with the opinions of experts from the flow of structuralist theory. Hadi Prayitno and Budi Santoso (1998: 50) said the development strategy in a developing country would be better to apply a development strategy by creating jobs, meeting basic living needs, developing human resources, relying on agriculture, developing integrated rural sectors and structuring the national economy Meanwhile, the development strategy in the era of autonomy must refer to the development of regional autonomy and the increasing independence and ability of the region in the implementation of development, which leads to the achievement of national and regional economic growth targets, increased life expectancy and welfare of the community, reduction of the poor and disadvantaged villages and increased active participation from the community. In this decade the focus of the development process is related to the problem of population, which in average in developing countries is increasing rapidly, urbanization, poverty, ignorance, community participation, sociopolitical organizations, environmental destruction and rural communities. But in this decade new problems still arise, namely the implementation of development has no 
dimension to human development, so that it will affect the problem of injustice, survival and inseparable development.

Sitimulyo Village, which is an inseparable part of development programs and policies in the Piyungan sub-district, Bantul, Yogyakarta Special Region. Various development programs and community empowerment carried out both through national and regional policies seek to make the community empowered so as to increase people's income in the household. One of the problems is how to increase community income in the household through an empowerment program when an empowerment program has been carried out but does not have a significant impact on increasing community income.

Community income according to Rosyidi (2006: 100-101) is an income in the form of money that flows from the business community to the community in the form of wages and salaries, interest, rent and profits. And that personal income (personal income) consists of salary, investment, interest, non-company corporate profits, transfer payments and entrepreneurship.

Community empowerment is an economic development tool that makes a community value in building in people-centered, participatory, empowerment and sustainable development (Chamber, 1995). The Chamber further explained that the concept of development with the community empowerment model does not merely fulfill the basic needs of the community but rather as an effort to find alternatives for local economic growth.

Community empowerment (empowerment) as an alternative strategy in development has developed in a variety of literature and thought, although in reality it has not been maximally implemented. Community development and empowerment is much discussed by the community because it is related to the progress and change of this nation in the future, especially if it is associated with community skills that are still lacking will greatly hamper economic growth itself. Empowerment is part of the development paradigm that focuses its attention on all the principal aspects of human beings in their environment, from intellectual (human resources), material and physical aspects, to managerial aspects. These aspects can be developed into socio-cultural, economic, political, security and environmental aspects (Thambu et al, 2020).

Therefore, to anticipate this situation, the government has issued regulations. The regulation was issued through the Ministry of Industry which has taken policy steps with the issuance of Regulation of the Minister of Industry Number 78 / M-IND / PER / 2007 concerning Increasing the Effectiveness of Small and Medium Industry Development through the One Village One Product Approach in the Center. This approach is intended to help the government in the distribution of business in each region so that it does not depend on the center.

The One Village One Product (OVOP) approach was developed by Morihiko Hiramatsu, a former MITI official who was elected as Governor of Oita in 1979. His tenure at Oita for 6 periods (1979-2003) was used as well as possible to alleviate the poverty of its citizens by implementing the idea of the concept of regional development and developing regional potential by involving community leaders, and the community itself, so that they are motivated to rise up and build their regions into prosperous regions and to empower the community.

The OVOP approach is an effort to reduce the gap from the impact of development activities in cities and villages by developing a people's economy based on local potential, developing products that are able to compete in the global market while still emphasizing local value added and encouraging the spirit of creating community independence. Initially, OVOP was launched as a policy in order to overcome the problem of depopulation caused by the younger generation who left their home areas and caused the local industry to slow down. In addition, the conception emphasized in this program is that what matters is not only economic prosperity (Gros National Product), but also inner satisfaction (Gros National Satisfaction) of the local community. 
According to Prayudi (2008), the background to the emergence of OVOP is three, namely: first, the concentration and density of population in urban areas as a result of urbanization patterns and cause a decline in rural population. Second, to be able to revive the movement and economic growth in the countryside, it is necessary to raise a wheel of economic activity that is suitable to the scale and size of the village by utilizing the potential and capabilities of the village and involving local community leaders. Third, reduce the dependence of rural communities that are too high on the regional and central government.

By using the OVOP strategy implemented it is expected to increase competitiveness with products from other countries that enter this country or meet the demand for products from other regions so that inter-regions can exchange their superior products. The success of a business activity will be achieved if the products we produce can "match" or "match" or "fit" the needs, desires and purchasing power of consumers.

One Village One Product (OVOP) approach since 2006 began to be studied and adopted by various countries, especially in Asia. OVOP is generally applied to resolve the social and economic disparities that occur between villages and cities in Asian countries. In addition, OVOP has also begun to be studied by countries in Africa, especially as one solution for poor areas which are still very dependent on the central government. In this section, it is explained about the application of OVOP in Asian countries which was started earlier than OVOP in Indonesia. Countries that adopt OVOP in Asia include Thailand (One Tambon One Product), Taiwan (One Town One Product), Malaysia (One District One Industry), Philippines (One Town One Product), and Cambodia (One Village One Product).

The application of OVOP in Indonesia has been carried out through the Ministry of Industry program since 2008 to develop the potential of small and medium industries in various sectors, including the handicraft sector. Ten regions selected by the Government to be developed with the OVOP approach are: Purwakarta (pottery / ornamental ceramics); Tasikmalaya (woven); Pekalongan (weaving and woven fragrant roots); Boyolali (handicraft institution); Bantul (earthenware / ceramics); Kulonprogo (woven); Bangli (woven bamboo); Tabanan (earthenware / ceramics); West Lombok (earthenware / ceramics); and Central Lombok (woven rattan and ate). These ten regions were chosen based on craft potential and preliminary research on regional core competencies that can be further developed. This process is fully implemented by the government with the assistance of consultants as third parties. The area that was the object of the case study in this study was the region in West Java, Purwakarta, with the main products as pottery or ornamental ceramics. The Purwakarta region was chosen as a case study in this study because pottery or ornamental ceramics in Purwakarta have been known since 1795 and still survive today. In addition, there are also some previous studies that examine the development of the earthenware industry in Purwakarta which can be used as a basis for comparing industrial conditions before and after the OVOP program is implemented (Meirina: 2012).

This research is expected to reveal and analyze the increase in community income through an empowerment program in Sitimulyo Village, Piyungan sub-district, Yogyakarta to strengthen and develop concepts and theories related to increasing community income through community empowerment programs. Yogyakarta in increasing community income through empowerment programs in the Sitimulyo Village, Piyungan Regency, Bantul, Yogyakarta.

\section{METHOD}

The study uses qualitative research methods, namely a contextual study that makes humans an instrument, and adapted to a reasonable situation in relation to the collection of data that are generally qualitative (Bungin, 2007). Through this design, a description of the phenomena, facts, nature and relationship of phenomena about increasing people's 
income through empowerment programs that are wholly and multidemensional so that the categorization and answers of research problems can be formulated as research findings.

Data obtained from interviews with 30 respondents from Sitimulyo Village, supported by observation. Data obtained from the field are analyzed through categorizing and reducing data, grouped data are then arranged in the form of narratives, interpreting data that has been grouped, making conclusions based on the narrative arrangement and verifying the results with the validity of the data through triangulation (Creswell, 1994) with inspection techniques that utilize data sources that are used both primary and secondary data, methods, theories, and the ability of researchers, so that this research becomes valid whose results can be justified.

\section{RESULT}

Siti Mulyo village, Piyungan sub-district is one of the villages located in Yogyakarta with a large percentage of land area, which is $9.40 .755 \mathrm{Ha}$. The population of Sitimulyo Village is 15,930 people with a population distribution that tends to be evenly distributed except in hilly areas. Residents tend to settle in groups in areas that have a flat and higher surface, hereinafter referred to as Dusun. With a total area of 940,755 hectares inhabited by 1980 population consisting of 985 men and 8705 women with 9075 heads of families (4254 heads of families classified as prehistoric families).

The population of Sitimulyo Village is dominated by residents with elementary school level (30.3\%) junior high school (30.89\%), high school (40.33\%), Academic (2.99\%), Bachelor (4.4\%), Masters ( $0.39 \%), \mathrm{S} 3(0.09 \%)$ The source of income of the $\mathrm{P}$ community of the Sitimulyo Village is closely related to the economic, agricultural, plantation, animal husbandry, quarrying, small industry handicraft, and services carried out by the community in supporting their income. day. Increased community income is an ability owned by the community through an increase in family purchasing power to finance the daily needs of the family both basic needs, social needs and other needs that can be seen from an increase in family income, family expenses (purchasing power) and the development of family savings .

Efforts to increase community income through empowerment programs conducted are the Empowerment Program through the OVOP approach namely One Vilage One Product not only creates one product but can have the skills and can sell it to increase the potential to become an entrepreneurship that can be increased to increase community income.

Efforts to increase community income through empowerment programs conducted are the Empowerment Program through the OVOP approach namely One Vilage One Product not only creates one product but can have the skills and can sell it to increase the potential to become an entrepreneurship that can be increased to increase community income.

The OVOP approach in training this activity refers to food processing learning activities and entrepreneurship training is classified into knowledge-transcience knowledge, which is developing knowledge and training life skills based on art, technology, and economics. This activity begins with training the ability of creative expression to express ideas and ideas to please others, and rationalized technologically so that these skills lead to an appreciation of renewable technology, ergonomic results and applicative in utilizing the surrounding environment by paying attention to their impact on ecosystems, management, and economics. Entrepreneurship training that will be applied is creativity, with creative abilities assisted by basic technology with an accurate work system that will produce high skill competencies.

Understanding of entrepreneurial skills is an effort to obtain fixed, fast, and appropriate competencies in dealing with skills problems. In this case, learning Food processing is designed as a learning process to change the behavior of trainees to be fixed, fast, and precise through food processing activities and processing technology. This 
skillful behavior is needed in human life skills in society. The trainees interact with craft products and technology in their environment, to be creative in creating various types of food products and technology products in order to obtain perceptual experiences, appreciative experiences, and creativity from the potential results of local environmental products.

The results of interviews conducted with 30 respondents namely the Sitimulyo village community about the empowerment program through the OVOP approach showed several things, namely:

1. That the empowerment program through the OVOP approach is training related to business development improvement activities that have been carried out by the government through village community empowerment activities.

2. Community participation in the training program is considered good by the government and the community self-help organization is successful because it is attended by the invited community.

3. Village officials always try to provide any kind of assistance in terms of tools, materials and services to succeed in community empowerment programs.

4. This training program will add to the people's insights and skills in making a product by utilizing a variety of local foods and so on until it can be produced which can later become an entrepreneur.

5. Enabling the village unit in monitoring the economic development of the community.

The concept of community empowerment as the theory of Kartasasmita (1996: 159-

160) which suggests three dimensions that influence community empowerment (1) enabling the creation of a climate that is able to encourage the development of community potential, (2) empowering that is the potential possessed by the community is further strengthened and (3) protecting that is the potential of a weak community in all respects the need for balanced protection so that the competition formed runs in a healthy manner. The empowering dimension is to strengthen the potential or power possessed by the community (empowering). In this framework, more positive steps are needed apart from just creating the climate and atmosphere. This reinforcement includes concrete steps and involves providing various inputs (inputs), as well as opening access to various opportunities (opportunities) that will make the community more empowered.

\section{DISCUSSION}

The Community Empowerment Program through the OVOP or One Vilage One Product approach is expected to be able to be independent in managing and developing entrepreneurial skills and training so that community income is increased, the fulfillment of the needs of business life is increasing. Increased income both in terms of trading, agriculture and animal husbandry business requires support from all parties including the availability of facilities and infrastructure.

Increasing community income is part of the implementation of development and equitable distribution of results to all levels of society without exception including community economic development. Empowerment of rural communities, among others, revolves around how to strive for rural communities to become the main actors in economic development and can utilize resources optimally and responsibly. The results of the non-physical financial assistance program cannot be directly seen, because it requires a long process of forming people's behavior, attitudes and culture. It could be started from the introduction, socialization, giving examples, training, counseling, and field practice. But what is certain is that people start and have the will, strength and increased ability to take advantage of their potential.

Empowerment of rural communities has become meaningful for increasing incomes, among others, revolving around how to strive for rural communities to become the main actors in economic development and be able to utilize resources optimally and 
responsibly with the community starting and having the will, strength and increasing ability to utilize their potential.

\section{CONCLUSION}

Based on the results of research and discussion, it was concluded that the Community Empowerment Program to Increase Community Income through empowerment programs, namely Community Empowerment with the OVOP approach or One Vilage One Product, which not only creates sautu products but also conducts skills training and has an entrepreneurial spirit. The empowerment program is directed at enabling the creation of a climate that is able to encourage the development of community potential, empowering namely the potential possessed by the community is further strengthened and (3) protecting the weak potential of the community in all respects the need for balanced protection so that the competition formed runs healthily as an effort to make the community have the ability to run a business so that it can increase people's income. However, with the various limitations faced by the community such as the fulfillment of life needs that are dominated by the level of consumption, lifestyle, sociocultural conditions and family dependents make an increase in income runs slowly.

From the conclusions, this study recommends a number of things, namely the need for further research in the case of the study of community income after empowerment through scientific studies with quantitative methods, the need for rural community empowerment programs in the economy through a definite policy, the need for a business partnership program from the private sector and BUMN / D to help capitalize the small business community in the village and the need for skills strengthening activities in the form of training needs to be done continuously by focusing on the community business sectors.

\section{REFERENCES}

Bungin, B. (2007). Qualitative research: communication, economics, public policy and other social sciences. Jakarta. Kencana Publisher.

Creswell, J. W. (1994). Qualitative inquiry and reasearch design. Sage. California.

Kartasasmita, G. (1996). Development for the people. Jakarta: PT Pustaka CIDESINDO.

Prayitno, H. \& Santoso, Budi, (1998). Development economics. Jakarta: Ghalia Indonesia.

Rosyidi, S. (2006). Introduction to economic theory: approaches to micro and macroeconomic theories. Jakarta: PT Raja Grafindo Persada.

Meirina, T, Dwinita, L. \& Susanto, R. (2012). One village one product (ovop) approach to develop potential crafts area case study: Pottery crafts in plered district, Purwakarta Regency, Bandung, ITB J. Vis. Art \& Des, Vol. 6(1).

Technical Assessment Manual. (2012). Directorate OVOP Product Classification and Development General of Small and Medium Industries at the Ministry of Industry.

Thambu, N., Prayitno, H. J., \& Zakaria, G. A. N. (2020). Incorporating Active Learning into Moral Education to Develop Multiple Intelligences: A Qualitative Approach. Indonesian Journal on Learning and Advanced Education (IJOLAE), 3(1), 17-29. 